\title{
Legal System of Modern Logistics of Exploration and Research
}

\author{
Xueqiang Li, Cai Su, Haizhong Bao, Hong Wang \\ Qingdao Huanghai Vocational college, Qingdao, China 266427 \\ 1013989742@qq.com,52462311@qq.com,794502741@qq.com,1617780761@qq.com
}

Keywords: Modern logistics, Legal system, The status quo, Advice

\begin{abstract}
Under the background of global economic integration, the logistics industry is faced with new opportunities and challenges. Existing in China's logistics laws and regulations can not meet the needs of the modern logistics development. Logistics in our country legislation status quo, analysis of problems existing in the legislation of our country logistics, and draws the experiences of developed country logistics, on the basis of logistics in China are put forward legislative Suggestions for improvement, strengthen the construction of legal system of modern logistics in our country.
\end{abstract}

\section{Introduction}

Logistics refers to the adjustment of laws and regulations in the logistics activities and legal norms of social relationships which related to logistics activities. Logistics activities related to the procurement, transportation, warehousing, production, circulation processing, distribution, Sales and other links. It closely related to capital, information and business. The specification of the logistics industry from the legal stratification Is the inevitable requirement of the development of the logistics industry. But so far, in China, because the influence of many logistics factors, we do a little research in the field of logistics legal system, such as the lack of a unified logistics technology and logistics service standards. The result is laws and regulations can not be timely service to the rapid development of the logistics industry. So far, all Legal norms related to logistics scattered in various laws of different departments. There is no such" logistics law" nor an independent legal sector. It is just a basic legal norms industry set. But we should know The legal system of logistics is a relatively independent legal norms which Consists of all logistics laws, including laws, regulations, rules and regulations, international convention, international practice. Modern logistics laws and regulations should be distinguished from traditional one. Adjusting the new things, show the characteristics of the times.

\section{The development status of domestic and abroad}

Healthy development of modern logistics industry depends on sound legal environment. Logistics industry is very important in some developed countries and governments which attach great importance to the legal system of environmental logistics development. In 1990, Japan enacted the "logistics". The promulgation of the law push the development of logistics industry in japan. According to their own national conditions, The United States, Germany, Britain, the Netherlands, Belgium and other countries have also developed the logistics industry policy and legal system. China's current legal system related to procurement transportation, warehousing, distribution, packaging, handling, distribution processing and so on. There are different levels of laws, regulations, departmental rules. But from the perspective of legal system, the present logistics laws and regulations exist serious defects. Laws and regulations to adjust China's logistics industry development contained in the civil law, contract law, maritime law and other relevant laws.

Of course there are relevant international practice, such as "Incoterms 2010" and so on. China's logistics contract belong to unnamed contract category, It only can be used in the relevant provisions of transport contract, custody contract, warehousing contract, etc. Named contract can achieve better results in specific disputes. In various aspects of logistics activities, the current legal 
system of China is not balanced. We should accelerate the pace of building the legal system and eliminate the lawless embarrassing situation and to pursuit the harmony between the legal structure.

Problems. From the perspective of legal system, the existing logistics laws and regulations exist serious defects.

Many logistics laws and regulations stand at a low level and effect, value target is difficult to coordinate. China's direct operational regulations is enacted by various ministries and the local government. It does not work effectivly and lack of legal responsibility. It is in the form of the "measures", the "Regulations", "notice" and other forms, so lack of general applicability in practice. And it is not good for the development of the logistics industry from macroscopic, so it is different to achive the value target of logistics laws.

The lack of systematicness and Special in law. At present, the logistics laws and regulations of our country and logistics related laws and regulations. In the industry management and content, it dispersed in the field of the sea, land, air transport, the protection of consumer rights and interests, business management and contract. It scattered in the form in all kinds of civil, administrative laws ,regulations and the rules of management measures ,so form a long and scattered situation and did not form a separate logistics code. Logistics law can not become an independent legal department.

Logistics legislation should keep pace with the times. Some logistics laws and regulations of our country still continue from the past planned economy era. These regulations in that time has played an active role, but due to the temporal and spatial differences, legal cross, legal blank, so under the environment of market economy, It is difficult to adapt to the current development of logistic, the internationalization of logistics development and amendment and repeal. Lack of specific guidance and adjustment of logistics practice, macro-control ability can not be pushed forward.

Keep the legislative system open to adapt to the rapidly changed new situation. With the development of logistics products, logistics technology, logistics standard and logistics service, The new object of logistics behavior appear and the traditional boundaries between separate law has been broken. Cross protection has become increasingly important. In China, the current legislation in these areas is quite weak, lack of coordination and prospective.

\section{Suggestions for improvement}

Modern logistics has become an important part of the national economy, especially in the third industry. According to statistics, logistics industry in USA accounted for more than $50 \%$ in the third industry and more than 30\% in Singapore. In recent years, Logistics in our country has developed very rapidly. The logistics industry is no longer the traditional simple transportation industry, but the system of the goods and materials engineering. Meanwhile, the orderly development of modern logistics industry is based on the good legal system. To establish independent legal system of logistics is the trend of modern logistics industry. The theory and practice of traditional logistics industry has laid a good foundation for constructing legal system. We need to integrate existing resources and Inherit the traditional rational ones. The first, we should consider the original laws develop original laws to adapt to the development of modern logistics industry.

Establish logistics legal system to adapt to market economy. Orderly development of the logistics economy needs the legal environment as the guarantee. We need logistics laws to strengthen the national macro-control and achive the the basic role of market in logistics resources. Establish a sound legal logistics system to to ensure the healthy development of the logistics industry in the market competition..

Planning a unified logistics industry, establishing logistics industry market. Logistics legal system should be defined as an organic whole, composed of many legal documents. To formulate a unified logistics regulations, it needs to Straighten out the relationships between the different logistics laws and regulations and clear the responsibility between Various departments. Also we need strengthen national management and to avoid the various differences and conflicts. 
Standardized and international , perfecting legal rules to adjust standard system. At present, compared with developed countries, China's logistics industry is still at a low level. For us, there is a long distance. Such as in the field of circulation, especially in the packaging, transportation and handling process, We have no technical standards. This has brought a great impact on the rapid development of the logistics industry. Therefore, It is absolutely imperative that we should develop and improve the national standards, and realize standards of logistics activities.

Improve logistics organization. We establish and perfect the logistics laws and regulations. At the same time, we also can not ignore the role of Logistics Industry association. We should fully mobilize the enthusiasm of the logistics industry organization. Let's logistics association regulate, guide the process of logistics development. Especially, without the timely adjustment of state laws and regulations in some countries, logistics association will play an irreplaceable role .So we should gradually establish different levels of logistics organization.

Pay attention to the logistics disaster emergency. Considering logistics regulations and in specific disaster emergency. Our country is vast in territory, in recent years, natural disasters is frequent. The establishment of emergency logistics is essential for emergency measures. Using advanced international experiences, we need to establish logistics emergency system to face organizing, purchasing, transportation and information. Strength the social emergency management and to realize the harmonious of human and nature. In 2009, development and Reform Commission in our country has launched a research "special plan". The "planning" will provide policy support for logistics emergency system.

Establish and improve the construction of local law. In view of vast territory in our country and difference of logistics development, We should consider the actual problems in the establishment of logistics law when make local logistics laws. At the same time, strengthen the regional communication to promote the development of the logistics industry better and faster.

Keeping pace with the times, improve the laws and regulations under the new situation actively.IOT is based on Internet, which tracks the goods. It involved many legal issues. So, Then, in the network era how to make use of the legal protection to protect IOT is an urgent problem to be solved. Our country should establish a unified standard of network, the legal protection of property and information. And Improve the logistics legal system in our country now.

\section{Summary}

In conclusion, development and prosperity of modern logistics industry depends on the legal system of fair and efficient environment. Market economy is legal economy, under it, Perfect legal system both provides the national macro management and guidelines for the micro activities of enterprises. To strengthen and improve our legal system of logistics and improve the logistics legal system of our environment will have significance for promoting the development of China's logistics industry.

\section{Acknowledgements}

This article is the subject: $<$ Shandong wisdom -- the Internet of things network information security legal support and protection System research>a research paper.

\section{Reference}

[1] YanjunZhou. (2012) Modern logistics legal systemization.Academic research Vol.(3)

[2] CaiSu ,XiaochenGao . (2014) Logistics laws and regulations. Beijing institute of technology press , Beijing

[3]HuaLiu. (2012)The us legal system of modern logistics and its revelation . Logistics technology, Vol.(31),142-143

[4]XuejiangLi .(2010)Logistics rationalization proposal in the development of laws and regulations. Logistics technology . Vol.(9) 